\title{
Хірургічне лікування вторинного гіперпаратиреозу у паціентів з хронічною хворобою нирок
}

\author{
Р. П. Ткаченко ${ }^{1}$, О. Г. Курик ${ }^{1,2}$, А. С. Головко ${ }^{2}$
}

${ }^{1}$ Науково-практичний центр профілактичної та клінічної медицини Державного управління справами, м. Київ,

${ }^{2}$ Національний медичний університет імені О. О. Богомольця, м. Київ

\section{Surgical treatment of secondary hyperparathyrosis in patients with chronic renal disease}

\author{
R. P. Tkachenko' ${ }^{1}$ O. G. Kuryk ${ }^{1,2}$, A. S. Golovko² \\ ${ }^{1}$ Scientific-Practical Centre for Prophylactic and Clinical Medicine State Directorate of Affairs, Kyiv, \\ ${ }^{2}$ Bogomolets National Medical University, Kyiv
}

\begin{abstract}
Реферат
Мета. Дослідити ефективність оперативного лікування вторинного гіперпаратиреозу (ВГПТ) у пацієнтів 3 хронічною хворобою нирок (XXН).

Матеріали і методи. Проведено ретроспективне дослідження результатів оперативних втручань на прищитоподібних залозах (ПЩЗ) та оцінено клініко-лабораторні показники у пацієнтів з ВГПТ.

Результати. Шляхом дослідження операційного матеріалу ПЩ3 62 пацієнтів дифузну гіперплазію встановлено у 8 (12,9\%, 95\% довірчого інтервалу (ДІ) 4,6 - 21,2\%), мікроаденоматоз - у 14 (22,6\%, 95\% ДІ 12,2 - 33,0\%); макроаденому - у 40 (64,5\%, 95\% ДІ 52,6 - 76,4\%). Із 40 пацієнтів з макроаденомами пухлини з головних клітин діагностовано у 32 (80\%, $95 \%$ ДI 67,9 - 92,4\%), онкоцитарні пухлини - у 8 (20\%, 95\% ДI 7,6 - 32,4\%). Відношення шансів (OR) - 16,0; $\chi^{2}-26,45 ; \mathrm{p}<0,0001$. Порівняння клініко-лабораторних показників через 1, 6 і 12 міс після оперативного втручання на ПЩ3, а також 3 показниками у пацієнтів, яким не виконували оперативного втручання, виявило статистично достовірні результати нормалізації рівнів паратиреоїдного гормону (ПТГ), кальцію (Са), фосфору (Р) і лужної фосфатази (ЛФ) у крові.

Висновки. Хірургічна операція при ВГПТ є ефективним методом лікування, який сприяє нормалізації лабораторних показників і попереджає важкі ускладнення.

Ключові слова: вторинний гіперпаратиреоз; третинний гіперпаратиреоз; паратиреоїдектомія; хронічна хвороба нирок.

Abstract

Objective. To investigate efficacy of operative treatment for secondary hyperparathyrosis in patients, suffering chronic renal disease.

Materials and methods. Retrospective investigation of results of operative interventions on parathyroid glands and cliniclaboratory indices in patients with secondary hyperparathyrosis were estimated.

Results. Using investigations of operative material of parathyroid glands in 62 patients, the following diagnosis were proved: diffuse hyperplasia - in 8 (12.9\%, 95\% trustworthy interval (TI), $4.6-21.2 \%)$, microadenomatosis - in 14 (22.6\%, $95 \%$ TI 12.2 - 33.0\%); macroadenoma - in 40 (64.5\%, 95\% TI 52.6 - 76.4\%). Of 40 patients with macroadenomas the tumors, consisting of main cells, were diagnosed in 32 (80\%, 95\% TI 67.9 - 92.4\%), oncocytic tumors - in 8 (20\%, 95\% TI 7.6 - 32.4\%). Odd's ratio (OR) $-16.0 ; \chi^{2}-26.45 ; \mathrm{p}<0.0001$.

Comparison of clinic-laboratory indices in 1,6 and $12 \mathrm{mo}$ in patients after operations on parathyroid glands and in those, to whom operative interventions were not performed, have had revealed statistically trustworthy results of normalization for levels of parathyroid hormone, calcium, phosphorus and alkaline phosphatase in the blood.

Conclusion. Surgical intervention for secondary hyperparathyrosis constitutes effective method of treatment, which promotes normalization of laboratory indices and prevents severe complications.

Keywords: secondary hyperparathyrosis; tertiary hyperparathyrosis; parathyroidectomy; chronic renal disease.
\end{abstract}

Висока частота та широка розповсюдженість ХХН, включаючи ниркову недостатність, що потребує застосування замісної ниркової терапії, викликає підвищену увагу до вибору правильної тактики діагностики та лікування таких хворих. Пацієнти із ХХН мають підвищений ризик порушень кісткової тканини, судинних аномалій, ранньої смертності внаслідок неконтрольованих змін обміну Са та Р [1]. В той час як у світлі останніх рекомендацій робиться акцент на лікуванні порушеної функції нирок [2], багато науковців у всьому світі загострюють увагу на ранніх змінах мінерального метаболізму, зокрема, на концентрації ПТГ [3]. Таким чином, ВГПТ, ремоделювання кісток та асоційована мінеральна дисфункція виникають у пацієнтів з XXН з безсимптомним перебігом або у тих, які ще не підозрюють про наявність даної патології.

Основним компонентом ВГПТ є хронічна стимуляція паратиреоцитів зовнішніми факторами: гіпокальціємією, гіперфосфатемією та зниженим синтезом активного 1,25дигідроксивітаміну $\mathrm{D}_{3}$ як наслідками патофізіологічних змін у пацієнтів з ХХH переважно у термінальній стадії.

На етапі лікування програмним гемодіалізом, коли хвороба невпинно прогресує, компенсаторні механізми 
порушеного гомеостазу втрачають свою ефективність. Проявами патологічних змін є порушення канальцевих механізмів регуляції та неспроможність відновити баланс Са та Р в крові внаслідок різкого зниження швидкості клубочкової фільтрації (ШКФ). Порушена функція нирок синтезувати активний вітамін $\mathrm{D}_{3}$ зумовлює гіпокальціємію та гіперплазію Пщз. Надлишок ПТГ зумовлює утворення малорозчинних фосфат-кальцієвих сполук та формування метастатичних кальцифікатів у вигляді відкладень у стінці судин, міокарді, м'яких тканинах, що призводить до незворотних ішемічних змін органів та судин, збільшуючи ризик смерті. Біль у кістках та суглобах, деформація кінцівок та спонтанні переломи є складовими остеодистрофічних змін при ВГПТ. Різноманітні прояви порушень мінерального та білкового обміну ускладнюють лабораторну діагностику ВГПТ при ХХН та вчасний вибір правильної лікувальної тактики.

Автономізація функції паратиреоцитів, викликана тривалою стимуляцією, призводить до некерованого пухлинного росту ПщЗ з розвитком аденом. На даному етапі, який має назву третинного гіперпаратиреозу (ТГПТ), завадити неконтрольованому прогресивному росту ПщЗ практично неможливо навіть у разі усунення першочергової етіології, наприклад, виконавши трансплантацію нирки.

Станом на сьогодні в Україні на програмному гемодіалізі перебуває близько 1500 осіб та ще не менше 25000 пацієнтів потребують такої терапії. Не менш вражаючими є статистичні показники у світі. Наприклад, у Сполучених Штатах Америки розповсюдженість ХХН становить 1968,2 спостереження на 1 мільйон населення, а щорічно вперше реєструють 358,6 хворих на 1 мільйон населення [4]. Створення можливостей своєчасного гемодіалізу здатне забезпечити 5-річне виживання до 75\% пацієнтів [5, 6].

У країнах, де діаліз широко застосовується, ВГПТ маЮть 30 - 50\% пацієнтів з ХХН $[1,7]$. У Европі та Австралії ВГПТ мають 30 - 49\% пацієнтів, що перебувають на діалі3i, у США цей показник сягає 54\% [7].

Проблема діагностики ВГПТ та ТГПТ стоїть на порядку денному у багатьох розвинених країнах, включаючи високорозвинені, де трансплантація нирки є стандартною процедурою [1]. Найбільш дискутабельним є визначення

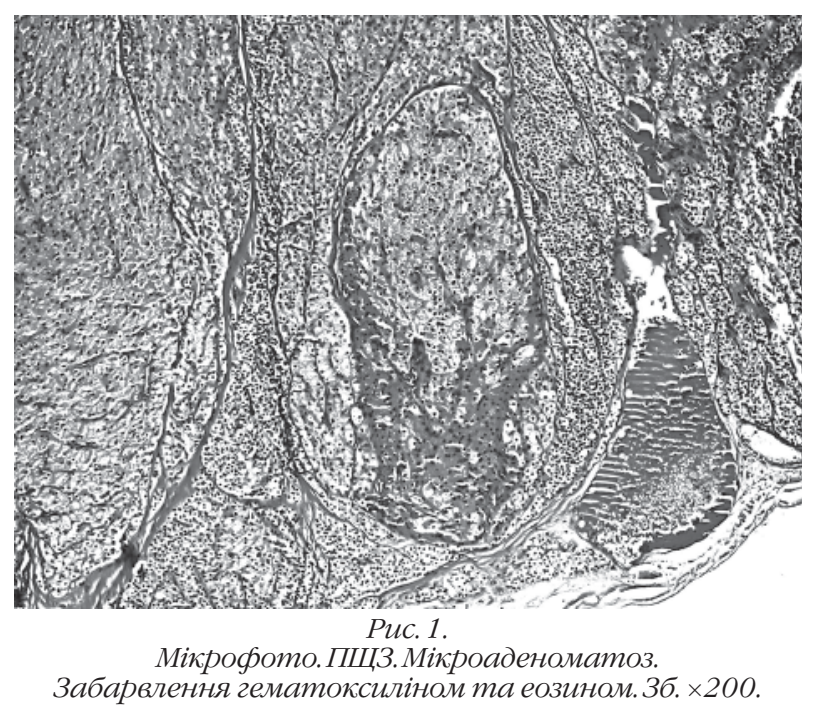

найбілыш виправданих методів консервативного лікування, діагностичних алгоритмів та абсолютних показань до оперативного втручання, обсягу та превентивних заходів попередження рецидиву.

Мета дослідження: вивчити ефективність методів оперативного лікування ВГПТ у пацієнтів з ХХН.

\section{Матеріали і методи дослідження}

У ретроспективному когортному дослідженні порівняно дані 62 хворих, які перебували на хронічному гемодіалізі та яким виконано паратиреоїдектомію (ПТЕ), та 64 хворих, які перебували на хронічному гемодіалізі та яким оперативного втручання не виконували.

У всіх пацієнтів визначали в крові рівні ПТГ, Са та іонізованого Са, Р, ЛФ, Са × Р, а також проводили інструментальні дослідження. Ультразвукове дослідження (УЗД) щитоподібної залози (Щ3) та ПЩЗ виконували на апараті Philips EnVisor $з$ лінійним датчиком 7,5 МГц з високою роздільною здатністю та встановлювали, чи вдається візуалізувати або визначити ступінь збільшення ПщЗ у двох вимірах. Наявність гіперфункції ПщЗ визначали додатково шля-

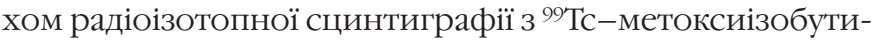
лізонітрилом (MIBI), яку проводили за двохетапною технікою на 10-й та 120-й хвилинах після внутрішньовенного введення радіофармпрепарату.

Статистичний аналіз клініко-лабораторних даних проведений за допомогою стандартних методів описової статистики у «Microsoft Excel 2010» («Microsoft Corp.»,USA). Показники представлені як середнє значення \pm стандартне відхилення (SD) при Ді 95\%. Дані були представлені до порівняння з використанням критерію Пірсона $\chi^{2}$ та визначено довірчий інтервал. Відмінності трактовані значущими при $\mathrm{p}<0,05$.

\section{Результати}

Пацієнти були у віці від 29 до 77 років, середній вік $(52,4 \pm 7,9)$ року. Відмінності пацієнтів за статтю не були статистично значущими.

У 62 пацієнтів після тотальної або субтотальної ПТЕ за відносними, абсолютними або життевими показаннями картина патоморфологічних змін при ВГПТ мала різні

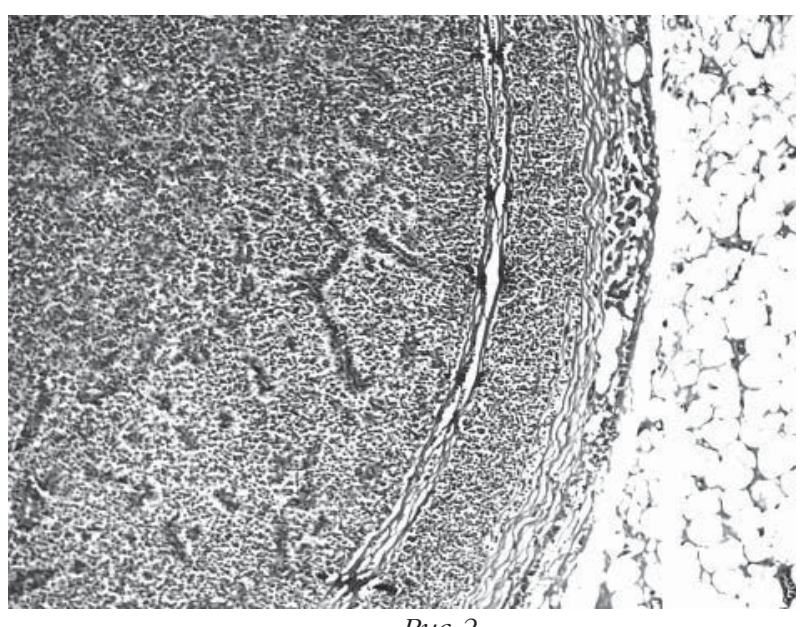

Мікрофото. ПщЗ. Аденома з головних клітин. Забарвлення гематоксиліном та еозином. 3б. ×100. 
складові. Дифузна гіперплаплазія - послідовне зменшення кількості жирових клітин строми та дифузна проліферація головних клітин, що набувала форми окремих вогнищ, тяжів або ацинарних структур. Мікроаденоматоз, або вузликова гіперплазія (до 5 мм в діаметрі) - проліферація головних або онкоцитарних клітин нодулярного типу, що прогресувала (рuс. 1). Характерним було також поширення дегенеративно-дистрофічних змін у вигляді ділянок фіброзу, крововиливів та утворення кіст. Прогресування мікроаденоматозу призводило до утворення аденом більше 5 мм у діаметрі (рис. 2).

За допомогою патоморфологічного дослідження операційного матеріалу ПщЗ 62 пацієнтів встановлені такі варіанти: дифузна гіперплазія - у 8 (12,9\%, 95\% ДІ 4,6 21,2\%) пацієнтів; мікроаденоматоз - у 14 (22,6\%, 95\% ДІ 12,2 - 33,0\%); макроаденома - у 40 (64,5\%, 95\% ДІ 52,6 $76,4 \%)$. Визначені такі різновиди макроаденом: пухлини з головних клітин - у 32 (80\%, 95\% ДІ 67,6 - 92,4\%) пацієнтів; онкоцитарні пухлини - у 8 (20\%, 95\% ДІ 7,6 - 32,4\%). Відношення шансів (OR) - 16,0; $\chi^{2}-26,45 ; \mathrm{p}<0,0001$.

При комплексному аналізі лабораторних показників порівнювали дані 62 пацієнтів до та після ПТЕ та 64 хворих, яким операція не була показана, проте у них був важкий перебіг ВГПТ та ХХН і вони тривалий час перебували на гемодіалізі. Через 12 міс після ПТЕ у пацієнтів спостерігали такі рівні лабораторних показників у порівнянні 3 групою пацієнтів з XXН, яким не виконували оперативного втручання: ПТГ - $(51 \pm 9,0)$ і $(681 \pm 27)$ пг млл, Са - $(2,01 \pm$ $0,08)$ і $(2,21 \pm 0,15)$ ммоль/л, Р - $(1,83 \pm 0,14)$ і $(2,09 \pm 0,15)$ ммоль/л, Са $\times \mathrm{P}-(3,81 \pm 0,15)$ і $(4,48 \pm 0,17)$ ммоль/л, ЛФ

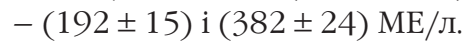

Найбілыш наочно та статистично достовірно реагували на проведення операції рівні в крові ПТГ та Са×Р ( $<<0,05)$.

\section{Обговорення}

Незважаючи на значне підвищення якості медикаментозного лікування та покращення якості діалізу у пацієнтів з ХХН ВГПТ розвивається дуже швидко і неконтрольовано. Значне зростання частоти ХХН частково пов'язане зі старінням населення та з підвищенням рівня виживаності пацієнтів після тяжких захворювань, що свідчить про покращення якості медичного забезпечення. Тому на даному етапі варто уникнути всіх можливих ускладнень ВГПТ, які можуть вплинути на якість та тривалість життя таких пацієнтів.

На думку деяких науковців, лише повна компенсація порушеної функції нирок у вигляді ниркового трансплантата здатна вплинути на перебіг захворювання, інакше ПТЕ не уникнути [8]. Проте за результатами нашого дослідження морфологічні зміни ПЩЗ при гіперпаратиреозі (ГПТ) ренального генезу демонструють такий ступінь переродження, що навіть у разі успішної операції з пересадки донорської нирки тотальна або субтотальна ПТЕ неминуча. Наявність аденоматозних змін залозистої паренхіми у вигляді макро- та мікроаденоматозу з переважанням макроаденом (65\%) свідчить про перехід ВГПТ у ТГПТ з автономізацією синтезу ПТГ та безперспективністю консервативного лікування. Превалювання ТГПТ за даними патоморфологічного дослідження вказує на недо- оцінку лікарями грубих ендокринологічних порушень у пацієнтів з ХХН та переоцінку ефективності медикаментозної терапії на даному етапі. Крім того, не варто нехтувати тим фактором, що 22\% хворих 3 мікроаденоматозом (нодулярною гіперплазією) ПщЗ складають пограничну групу пацієнтів з морфологічними передумовами для розвитку неконтрольованої функції паратиреоцитів та переходу ВГПТ у ТГПТ.

Згідно з міжнародними стандартами початкове лікування ХХН та ГПТ ренального генезу є медикаментозним [8]. Контроль рівня активного 1,25-дигідроксивітаміну $\mathrm{D}_{3}$, Ca, застосування фосфатних біндерів та клінакальцету дає змогу оцінювати мінеральний гомеостаз тривалий час тільки за умови, що трансплантація нирки буде виконана вчасно і ренальний ГПТ вдасться компенсувати. Останнім часом частоту ПТЕ вдалося знизити до 1 2\% у деяких нефрологічних центрах саме завдяки успішно налагодженій процедурі трансплантації та застосуванню клінакальцету [9]. Проте навіть у країнах, де трансплантація нирки давно є рутинною процедурою, частота ВГПТ залишається гострим питанням $[1,7]$.

Автори оглядів літератури та оригінальних досліджень наводять контраверсійні позиції та оцінки застосування ПТЕ з поглядів хірургії та нефрології. Обмежені результати ефективності хірургічного втручання у пацієнтів 3 ВГПТ на фоні ХХН зумовлюють те, що для нефрологів у світі ПТЕ рідко є складовою алгоритму. Саме результатів мультицентрового рандомізованого контрольованого дослідження бракує на сучасному етапі.

Оцінити та обрати найбільш оптимальний об'єм ПТЕ з приводу ВГПТ, базуючись на міжнародній літературі, складно, оскільки доказовість стандартної білатеральної ревізії та ідентифікації усіх чотирьох ПщЗ залишається переконливою: рівень доказовості (РД) - 1 - 2, ступінь рекомендаціі (СР) - А. До порівняння пропонують чотири загальні процедури у вигляді субтотальної ПТЕ із стандартною білатеральною тимектомією (сПТЕ), тотальної ПТЕ з аутотрансплантацією (АТ) та білатеральною тимектомією (тПТЕ/АТ), тотальної ПТЕ без АТ з білатеральною тимектомією (тПТЕ/бАТ) та тотальної ПТЕ з білатеральною тимектомією (тПТЕ/зТЕ), що унеможливлює вироблення єдиних загальних рекомендацій $[10,11]$. Останні дані вказують на кращі результати сПТЕ та тПТЕ/АТ: кращий післяопераційний ефект з уникненням тимчасового гіпопаратиреозу [8]. Більшість науковців схиляються до вибору сПТЕ, якщо є шанс на проведення трансплантації нирки у найближчий час після сПТЕ $[12,13]$. Останні дослідження підтверджують, що після ПТЕ стійко підвищується рівень креатиніну у крові внаслідок зниження ШКФ у пацієнтів після трансплантації [14]. Гіперкальціємія патогенетично знижує ШКФ, індукуючи ниркову вазоконстрикцію та нефрокальциноз, тому при корекції рівня кальцію функція трансплантата не має бути порушена, а отже, пояснити порушену ниркову функцію у ранньому періоді після сПТЕ можливо гемодинамічним ефектом ПТГ. При ВГПТ ПТГ спричиняв посилений вазодилатуючий ефект на прегломерулярні капіляри за звужених еферентних артеріол. Коли рівень ПТГ повернувся до стандартних значень, реверсивний ефект на ренальні капі- 
ляри міг викликати такі короткочасні порушення ниркової функції, і тому порівняння тривалості життя пацієнтів з нирковим трансплантатом після виконання ПТЕ та без операції на ПщЗ не виявило статистично значущих відмінностей. Також порівняння ШКФ у пацієнтів з трансплантованою ниркою показало, що цей показник був вищим у хворих після ПТЕ, виконаної до пересадки органа, ніж у хворих, яким першочергово виконали трансплантацію, а ПТЕ опісля [15].

Незважаючи на велику кількість літературних даних та матеріали власних досліджень, вибір єдиного алгоритму лікування пацієнтів з ХХН та ВГПТ є обмеженим і недосконалим. Необхідні подальші дослідження з однорідними групами вибірки пацієнтів для формування затверджених рекомендацій та показань до оперативного втручання, консервативного лікування, діагностичних та прогностичних критеріїв високого рівня доказовості.

\section{Висновки}

1. У більшості ПщЗ, видалених під час операцій з приводу важких форм ВГПТ ренального генезу, наявні аденоматозні зміни залозистої паренхіми у вигляді мікро- та макроаденоматозу, причому в 65\% спостережень переважали макроаденоми, що свідчить про перехід ВГПТ у ТГПТ.

2. Хірургічна операція при ВГПТ є ефективним методом лікування, який дає змогу нормалізувати лабораторні показники і попередити важкі ускладнення.

\section{Referance}

1. Hedgeman E, Lipworth L, Lowe K, Saran R, Do T, Fryzek J. International Burden of Chronic Kidney Disease and Secondary Hyperparathyroidism: A Systematic Review of the Literature and Available Data. International Journal of Nephrology. 2015;5(3):1-15.

2. Kidney Disease: Improving Global Outcomes (KDIGO) CKDMBD Work Group. KDIGO clinical practice guideline for the diagnosis, evaluation, prevention, and treatment of Chronic Kidney Disease-Mineral and Bone Disorder (CKD-MBD). Kidney Int Suppl. 2009;113:1-130.

3. Levin A, Bakris GL, Molitch, Smulders M, Tian J, Williams LA, Andress DL. Prevalence of abnormal serum vitamin D, PTH, calcium, and phosphorus in patients with chronic kidney disease: results of the study to evaluate early kidney disease. Kidney International. 2007; 71(1):31-8.

4. Collins AJ, Foley RN, Gilbertson DT, Chen S. United States Renal Data System public health surveillance of chronic kidney disease and endstage renal disease. Kidney Int Suppl. 2015;5(1):2-7.

5. Stewart JH, McCredie MRE, Williams SM. Geographic, ethnic, age-related and temporal variation in the incidence of end-stage renal disease in Europe, Canada and the Asia-Pacific region, 1998-2002. Nephrology Dialysis Transplantation. 2006;21(8):2178-83.

6. Noordzij M, Kramer A, Abad Diez JM, Alonso de la Torre R, Arcos Fuster E, Bikbov BT, et al. Renal replacement therapy in Europe: a summary of the 2011 ERA-EDTA Registry Annual Report. Clin Kidney J. 2014;7(2):227-38.

7. Robinson BM, Bieber B, Pisoni RL, Port FK. Dialysis Outcomes and Practice Patterns Study (DOPPS): Its Strengths, Limitations, and Role in Informing Practices and Policies. Clin J Am Soc Nephrol. 2012;7:1897905 .

8. Lorenz K, Bartsch DK, Sancho JJ, Guigard S, Triponez F. Surgical management of secondary hyperparathyroidism in chronic kidney disease - a consensus report of the European Society of Endocrine Surgeons. Langenbecks Arch Surg. 2015;400(8):907-27.

9. Pitt SC, Sippel RS, Chen H. Secondary and tertiary hyperparathyroidism, state of the art surgical management. Surg Clin North Am. 2009;89(5):1227-39.

10. Madorin C, Owen RP, Fraser WD, Pellitteri PK, Radbill B, Rinaldo A, et al. The surgical management of renal hyperparathyroidism. Eur Arch Otorhinolaryngol. 2012;269(6):1565-76.

11. Schneider R, Bartsch DK. Role of surgery in the treatment of renal secondary hyperparathyroidism. Br J Surg. 2015;102(4):289-90.

12. Lorenz K, Sekulla C, Dralle H. Chirurgisches Management des renalen Hyperparathyreoidismus. Zentralbl Chir. 2013; 138(2): 47-54.

13. Schneider R, Bartsch DK, Schlosser K. Relevance of bilateral cervical thymectomy in patients with renal hyperparathyroidism: analysis of 161 patients undergoing reoperative parathyroidectomy. World J Surg. 2013;37(9):2155-61.

14. Evenepoel P, Claes K, Kuypers D, Maes B, Vanrenterghem Y. Impact of parathyroidectomy on renal graft function, blood pressure and serum lipids in kidney transplant recipients: a single centre study. Nephrol Dial Transplant. 2005;20(8):1714-20.

15. Jeon HJ, Kim YJ, Kwon HY, Koo TY, Baek SH, Kim HJ, et al. Impact of parathyroidectomy on allograft outcomes in kidney transplantation. Transpl Int. 2012; 25(12):1248-56. 